\title{
Analisis Konstruk Fashion Involvement Remaja Pada Masa Pandemi Covid-19
}

\author{
Sumi Lestari ${ }^{1}$ \\ ${ }^{1}$ Jurusan Psikologi, Fakultas Ilmu sosial dan Ilmu Politik \\ Universitas Brawijaya \\ ${ }^{1}$ Lestari.sumi@ub.ac.id
}

\begin{abstract}
The purpose of this study is to examine the relationship between self confidence with adversity quotient of post-drop out students at Universitas Trunojoyo Madura. The hypothesis is that there is a relationship between self confidence and adversity quotient in post-drop out students at Universitas Trunojoyo Madura. The research method is a quantitative approach. The number of participants was 130 people with a purposive sampling technique. The scale used is a scale of self confidence and adversity quotient. Data analysis using the Spearman Rank and analyzed using the SPSS 23.0 program. The results show the correlation is 0.844 (significance level $0.000<0.05$ ) which means the level of relationship between variables is very strong. It illustrates that there is a positive relationship between self confidence and adversity quotient in post-drop out students at Universitas Trunojoyo Madura. In other words, the hypothesis is accepted.
\end{abstract}

Key Words: Self Confidence, Adversity Quotient, Students, Drop Out

\begin{abstract}
Abstrak
Tujuan dari penelitian ini yaitu menguji hubungan self confidence dengan adversity quotient mahasiswa pasca drop out di Universitas Trunojoyo Madura. Adapun hipotesisnya adalah ada hubungan antara self confidence dengan adversity quotient pada mahasiswa pasca drop out di Universitas Trunojoyo Madura. Metode penelitiannya adalah dengan pendekatan kuantitatif. Jumlah partisipannya sejumlah 130 orang dengan teknik purposive sampling. Skala yang digunakan adalah skala self confidence dan adversity quotient. Analisis data memakai Spearman Rank serta dianalisis menggunakan program SPSS 23.0. Hasil menunjukkan korelasinya adalah sebesar 0,844 (taraf signifikansi $0.000<0,05$ ) yang artinya tingkat hubungan antar variabel adalah sangat kuat. Hal itu menggambarkan ada hubungan positif antara self confidence dengan adversity quotient pada mahasiswa pasca drop out di Universitas Trunojoyo Madura. Dengan kata lain, hipotesis diterima.
\end{abstract}

Kata Kunci: Self Confidence, Adversity Quotient, Mahasiswa, Drop Out

\section{Pendahuluan}

Ilmu psikologi merupakan ilmu perilaku dimana berkaitan erat dengan perilaku berpakaian, ber-make up dan memilih model-model terkini, individu mempersuasi diri sendiri dengan mengenakan pakaian model terkini, enak dipandang, senada antara pakaian dengan make up dianggap mampu mengikuti 
perkembangan zaman dan atau fashionable alias tidak cupu, jadul dan konvensional, dampaknya maka akan banyak orang lain yang memberikan penilaian positif bahkan menjadi trend bagi lingkungannya (Iravania, Ghojavanda, Taghipourb dan Masomi, 2012).

Hendraningrum, dan Susilo (2008) mendiskripsikan bawa di era globalisasi fashion merupakan sebuah kebutuhan primer yang harus dicukupi selain sebagai gaya hidup (lifestyle) di seluruh dunia. Penampilan yang menarik, rapi, mempesona, bagus, matching, good looking, enak dipandang menjadi sasaran prioritas setiap individu untuk menilai karakteristik orang lain dan bahkan dalam dunia kerja pun para karyawan berlomba-lomba memakai pakaian yang akan menunjang performanya.

Breward (Hines dan Bruce, 2003) menjelaskan bahwa fashion sebagai suatu media penting dalam mengekspresikan status sosial, estetik, ide dan atribut yang melekat pada seseorang. Seseorang berpakaian berdasarkan pada fashion sebagai bentuk cerminan kepribadian, percaya diri, mood, situasi, dan status sosial seseorang. Senada dengan Breward, Newman (2001) menyatakan bahwa fashion yang digunakan oleh seseorang menunjukkan identitas sosial di hadapan masyarakat, artinya bahawa pakaian yang dikenakan seseorang merupakan salah satu upaya atau cara seseorang mengkomunikasikan identitasnya terhadap orang di sekitarnya. Selain itu fashion merupakan suatu bentuk penghargaan seseorang terhadap dirinya dan keluarganya.

Berpakaian merupakan cara yang paling mudah seseorang mengekspresikan tingkat kesejahteraan dan kondisi ekonominya. Fashion pun dianggap sebagai bentuk penyesuaian seseorang terhadap perkembangan terkini misal. Gaya berpakaian, gaya make up dan brand-brand kecantikan terkini meliputi tas, sepatu dan make up yang lagi hits. Untuk menyesuaikan diri terhadap perkembangan dan perubahan yang terjadi maka seseorang membutuhkan upaya keras dan materi yang tidak sedikit, karena trend mode bersifat dinamis selalu mengalami perubahan dari waktu ke waktu (Fenigstein, Scheier dan buss, 1975).

Selain itu Andriyanti, Sukmana, Suyadi dan Fanani (2016) menyatakan bahwa motivasi seseorang mengikuti mode atau memilih fashion tertentu dikarenakan adanya konformitas, keinginan mencari variasi gaya berpakaian, kebutuhanuntuk mengekspresikan kreativitas dirinya, menambah percaya diri, dan mempengaruhi citra diri pada seseorang serta berpengaruh pada 
pembentukankonsep diri seseorang. Selain itu mengikuti perkembangan fashion terkini memiliki konotasi positif yaitu terlihat lebih unggul dibandingkan yang tidak mengikuti dan mengetahui trend fashion terbaru serta bentuk penegasan akan identitas diri seseorang terhadap lingkungan sosialnya.

Trend fashion atau trend mode selalu mengikuti perkembangan dan situasi zaman, begitu halnya situasi dan keadaan pada masa pandemi corona virus desease19 (covid-19), pemerintah mewajibkan menggunakan masker saat melakukan aktivitas di luar rumah untuk menjaga agar tidak tertular virus korona-19 dan memutus mata rantai covid-19, masker dan face shield merupakan trend terbaru pada masa covid-19 selain fungsinya sebagai pengaman namun bagi remaja masker dan face shield memiliki nilai artistik. Selain itu sebagaian remaja mengikuti trend mode terkini dengan menggunakan masker dengan model dan aksen tertentu guna sebagai bentuk presentasi diri remaja, hal ini dapat kita jumpai dibeberapa toko online atau daring maupun offline (luring) dengan berbagai macam aneka mode masker dengan menggunakan berbagai macam asesories maupun gambar-gambar sebagai bentuk dari fashion involvement.

Lebih lanjut Amiri, Jasour, Shirpor dan Alizadeh (2012) menjelaskan bahwa remaja mengikuti trend merupakan bentuk eksistensi diri dan berpengaruh secara signifikan terhadap citra diri, percaya diri, harga diri dan bahkan konsep diri remaja. Masa remaja merupakan masa perkembangan fisik secara optimal sehingga mereka cenderung sensitif terhadap penampilan dirinya, remaja berusaha mengikuti trend mode terkini dan bahkan mereka berusaha menjadi trendsetter bagi kalangan mereka. Dengan dianggap fashionable maka akan menambah percaya diri pada remaja, bahagia, excited karena menjadi kiblat trend terbaru. Remaja lebih merasa senang, bangga dan berprestasi ketika diaggap sebagai trendsetter dari pada trend follower.

Lebih lanjut Bernard (2011) menjelaskana bahwa fashion merupakan salah satu bentuk penghargaan seseorang terhadap diri dan orang lain, sebagai symbol status yang sedangkan diperankan, sebagai penanda yang paling tampak karena dengan fashion maka seseorang mudah mengidentifikasi status sosial, gaya hidup, karakter dan bahkan kepribadian pemakiannya. Alasan individu tertarik pada fashion dalam kehidupan sehari-hari adalah untuk memoles penampilan agar 
terlihat cantik dan menarik, terlihat lebih sopan, daya tarik tubuh positif, good looking, fashionable dan trendy. Fashion merupakan salah satu pilihan gaya hidup individu agar mereka merasa lebih nayaman dan penampilan terlihat lebih baik.

Fashion involvement adalah respon individu dalam menanggapi model fashion dikarenakan adanya kebutuhan, kepentingan, ketertarikan individu terhadap produk nilai yang melekat pada fashion terbaru (Japrianto dan Sugiharto, 2011). Senada dengan Japrianto dan Sugiharto, Kim (2005) berpendapat bahwa fashion involvement merupakan suatu tanggapan individu terhadap produk fashion terbaru karena adanya anggapan tingkat kepentingan terhadap produk yang diharapkan. Menurut Goldsmith, Moore dan Beaudoin (1999) fashion involvement merupakan suatu bentuk keterlibatan individu pada suatu produk fashion terkini disebabkan karena adanya kebutuhan, ketertarikan, dan kepentingan individu.

Park dan Lennon (2006) menjelaskan bahwa fashion involvement merupakan suatu keterlibatan individu secara motivasional atau suatu kepentingan yang ditimbulkan oleh adanya situasi tertentu dan direfleksikan melalui penampilan. Fairhurst, Good dan Gentry (1989) keterlibatan pada model fashion terbaru berkaitan erat dengan karakteristik individu dan pengetahuan terhadap perkembangan fashion yang akan mempengaruhi pola pikir, kepercayaan, harga diri, konsep diri dan bahkan pengambilan keputusan dalam membeli produk model fashion terbaru. Berdasarkan uraian permasalahan-permasalahan terkait dengan fashion involvement maka dapat pertanyaan dalam penelitian ini adalah bagaimana gambaran persepsi remaja terhadap fashion involvement pada masa pandemic covid-19?. Penelitian ini dilakukan dengan tujuan untuk menggambarkan persepsi remaja terhadap fashion involvement di masa pandemic covid-19.

\section{Metode Penelitian}

Penelitian ini menggunakan metode penelitian survey dengan memberikan pertanyaan terbuka terkait dengan fashion involvement secara online. Teknik pengambilan sampel dengan menggunakan online melalui google.form. Jumlah responden dalam penelitian ini adalalah 301 remaja di Jawa Timur. Analisis data dalam penelitian ini dengan menggunakan teknik analisis tematik Boyatzis (1998) yaitu cara pandang dalam perspektif tematik bersifat rinci, detil, mendalam dalam 
menganalisa data, fenomena, gejala dan tema-tema yang ditemukan lebih akurat dan dekat dengan situasi yang sebenarnya. Analisis tematik dalam penelitian ini dengan menggunakan analisis tematik deduktif atau based on theory, berikut ini beberapa langkah-langkah dalam proses analisis tematik deduktif Boyatzis, sebagai berikut ini:

- Membuat tema dengan menentukan kode, label, definisi dan indikator dari kontruk tema yang telah ditemukan.

- Membuat transkrip dan catatan refleksi disetiap respon dari responden, dengan mengelompokkan dan memberikan koding warna maupun angka pada pengelompokan tema yang sama.

- Memberikan diskripsi atau narasi dari pengelompokan atau pengorganisasian tema yang telah ditemukan.

Kredibilitas atau validitas dalam penelitian ini dengan menggunakan kredibilitas komunikatif dan reliabilitas atau dependibilitas dalam penelitian ini menggunakan triangulasi.

\section{Hasil}

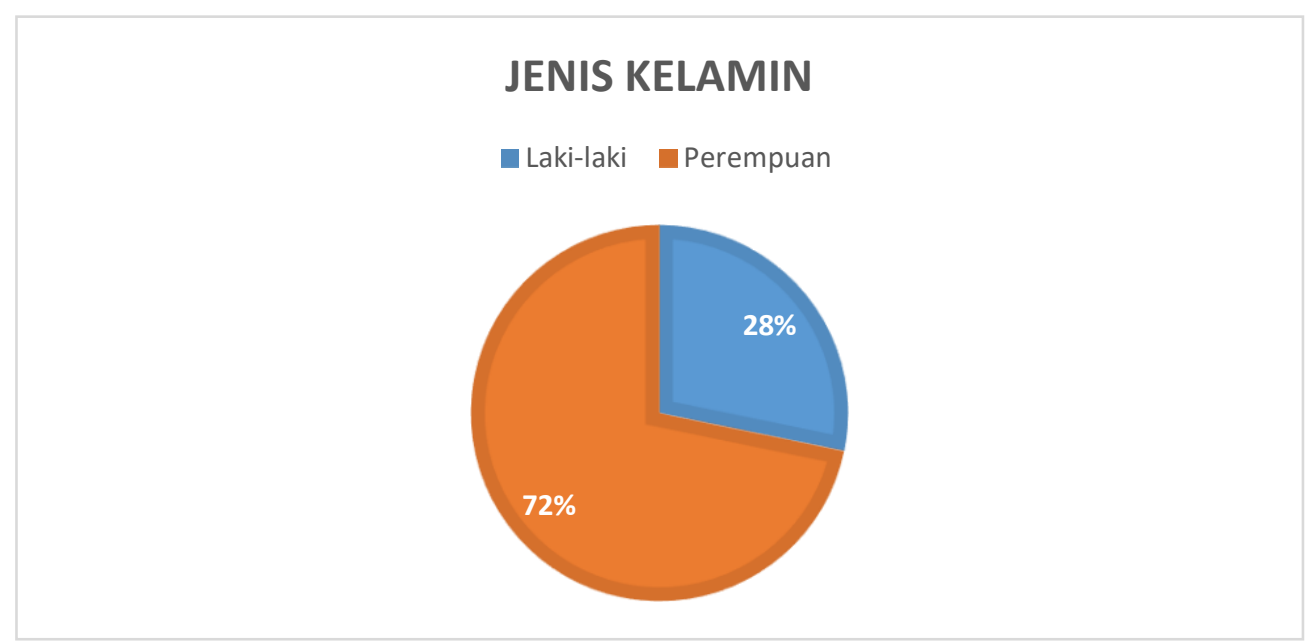

\section{Gambar 1. Jenis kelamin responden penelitian}

Tabel di atas menunjukkan bahwa responden dalam penelitian ini $71,8 \%$ atau sebanyak 216 berjenis kelamin perempuan. Sedangkan untuk responden laki- 
laki berjumlah $28,2 \%$ atau 85 responden, dengan jumlah total responden 301 remaja laki-laki mapun perempuan di Jawa Timur.

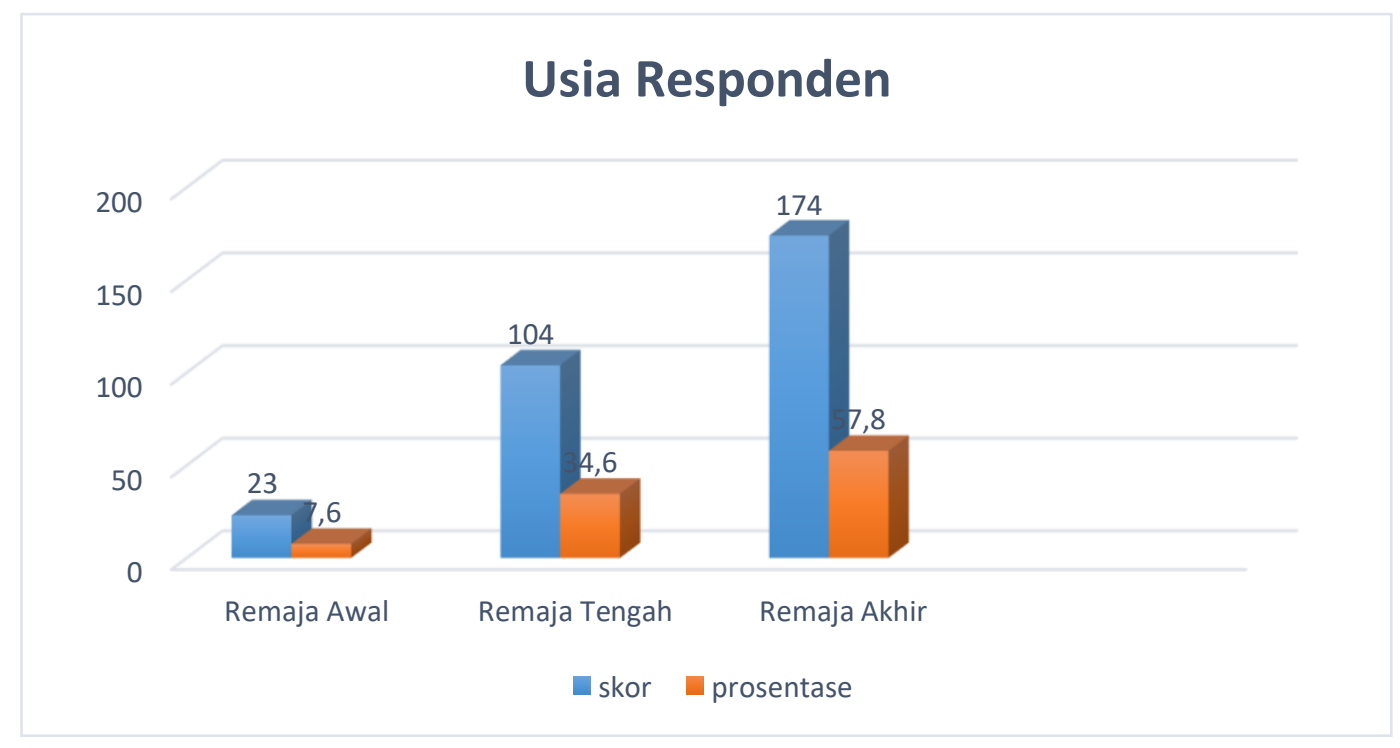

\section{Gambar 2. Usia responden penelitian}

Responden dalam penelitian ini adalah remaja pada dengan rentang masa remaja awal hingga remaja akhir, dalam penelitian ini reponden didominasi oleh remaja akhir (usia 20-23 tahun) dengan jumlah reseponden 174 atau 57,8\%, usia remaja tengah (usia 16-19 tahun) sebanyak 104 responden atau 34,6\% dan usia remaja awal (usia 12-15 tahun) berjumlah 23 responden atau 7,6\%.

Jumlah responden dalam penelitian ini 301 remaja dengan memberikan lima pertanyaan terbuka antara lain;

1. Pertanyaan pertama tentang model fashion terkini. Berikut ini table model fashion terkini pada remaja di masa pandemic.

\section{Table 1}

\section{Fashion Terkini pada Remaja}

\begin{tabular}{llll}
\hline No & \multicolumn{1}{c}{ Clustering thema Model Fashion terkini } & Jumlah & Prosentase \\
\hline 1 & $\begin{array}{l}\text { Casual dengan menggunakan masker warna } \\
\text { senada }\end{array}$ & 52 & 17,3 \\
\hline 2 & Simpel dengan masker warna yang matching & 47 & 15,6 \\
\hline 3 & 90 'an & 36 & 12 \\
\hline 4 & $\begin{array}{l}\text { Muslim dengan menggunakan masker dana } \\
\text { atau cadar }\end{array}$ & 35 & 11,6 \\
\hline 5 & Personality fashion & 21 & 7 \\
\hline 6 & Korean dan western style & 20 & 6,6 \\
\hline
\end{tabular}




\begin{tabular}{llll}
\hline 7 & Unik & 16 & 5,5 \\
\hline 8 & Elegan & 15 & 5,3 \\
\hline 9 & Warna tertentu & 14 & 5 \\
\hline 10 & Fashion terbaik & 13 & 4,8 \\
\hline 11 & Hits & 9 & 2,9 \\
\hline 12 & Branded & 6 & 2 \\
\hline 13 & Comfortable & 6 & 2 \\
\hline 14 & Urban style & 4 & 1,3 \\
\hline 15 & Bohemian style & 3 & 0,9 \\
\hline 16 & Rose fashion style & 2 & 0,6 \\
\hline Jumlah total & 301 & 100
\end{tabular}

Dari ke 301 Responden terdapat 17,3\% responden menjawab model casual merupakan pilihan tertinggi model terbaru dilengkapi masker yang senada dengan pakaian yang digunakan, 15,6\% responden menjawab fashion terkini adalah yang simple dengan mengikuti perkembangan terkini tidak terkecuali masker sebagai aksen asesories di era wabah covid-19. Sebesar $12 \%$ responden menjawab bahwa fashion terkini adalah yang fashion pada masa tahun 1990 an. Korean dan Western style merupakan salah satu jawaban responden terkait dengan fashion terkini di kalangan remaja masa wabah covid-19 sebesar 20 responden dan sekitar 6,6\%, selain itu terdapat jawaban dari responden rose fashion style yakni fashion yang digunakan oleh rose blackpink, lebih lanjut responden menjawab fashion terkini adalah bohemian fashion yakni jenis fashion yang dikenal dengan gayanya yang hippie yang mengusung konsep eksentrik dengan perpaduan warna cerah pada pakaian yang dikenakan dan menggunakan periasan dengan ukuran besar. Contohnya baju gombrong dengan paduan maxi skirt atau celana cutbar dengan atasan kaos stripes ketat, sepatu boots dan aksesori yang terkesan nyeleneh dan eksentrik. Berikut ini beberapa respon dari responden.

\footnotetext{
"Menurut saya model fashion terkini adalah model fashion yang mengarah pada korean style atau western style dan menggunakan masker saat aktivitas di luar rumah"

"Fashion terkini menurut saya kasual, simpel, comfy dengan ditambah aksen masker warna senada"

"masih seputar casual look sih. lagi rame koleksi hoodie di mall maupun butikbutik"

"Yang simple2 aja d pake tp elegan kornya skrg ada d korea sih, apa apa korea apa apa korea jd fokusnya”
} 
"yg casual sederhana tapi tetap fashionable (denim, converse, polo) ditambah masker warna gelap"

2. Pertanyaan kedua terkait koleksi responden dalam memiliki fashion terkini lebih dari satu.

Tabel 2

Koleksi Responden dalam Memiliki Fashion Terkini

\begin{tabular}{llll}
\hline No & Keterangan & Jumlah & Prosentase \\
\hline 1 & Memiliki & 294 & 97,7 \\
\hline 2 & Tidak memiliki & 7 & 2,3 \\
\hline Jumlah total & 301 & 100 \\
\hline
\end{tabular}

Dari 301 responden remaja menjawab hampir 97,7\% responden memiliki koleksi fashion terkini lebih dari satu dan sisanya sebanyak 7 atau $2,3 \%$ menyatakan tidak memiliki. Berikut beberapa respon dari responden.

"Kalau baju,tas,jam emang koleksi dong..kan buat ganti"

"Dari dulu ridak ada ya karna saya hnya mengikuti gaya berpakaian dan fashion terkini korea saja”

"Ya, saya suka mencoba style baju yang menurut saya kekinian”

"saya cenderung memilih fashion yang casual, selain itu saya tertarik dengan fashion yg dekat sekali dengan ethic kebudayaan dari suatu negara”.

"Saya memiliki lebih dari satu fashion terkini. High waist jeans dan floral midi dress"

3. Pertanyaan ketiga seberapa penting mengikuti fashion involvement atau trend mode.

Table 3

Seberapa Penting Fashion Involvement pada Remaja.

\begin{tabular}{llll}
\hline No & Seberapa penting mengikuti fashion terkini & Jumlah & Prosentase \\
\hline 1 & Tidak penting & 25 & 8,3 \\
\hline 2 & Tidak terlalu penting & 100 & 33,2 \\
\hline 3 & Cukup penting & 31 & 10,3 \\
\hline 4 & Penting & 90 & 29,9 \\
\hline 5 & Sangat penting & 55 & 18,3 \\
\hline Jumlah total & 301 & 100
\end{tabular}


Pada pertanyaan ketiga 301 responden menjawab sangat penting, penting, cukup penting dan tidak terlalu penting serta tidak penting. Terdapat 55 responden atau sebesar $18,3 \%$ responden menjawab bahwa mengikuti fashion terkini merupakan suatu hal yang sangat penting dalam menunjang penampilan diri dan percaya dirinya serta wawasan yang dimiliki oleh individu, sebesar 29,9\% responden atau sebenyak 90 responden menjawab cukup penting karena dengan menggunakan fashion terkini akan menjadi trendsetter bagi kalangan remaja lainnya, dan itu merupakan suatu kebanggaan dan hits di era sekarang ini, sebanyak 100 responden atau sebesar 33,3\% responden menyatakan mengikuti fashion terkini (fashion involvement) tidaklah terlalu penting, karena mereka menyadari bahwa daya tarik dan kesempurnaan penampilan tidak hanya terletak pada penggunaan fashion terkini atau pada penampilan fisik semata.

\footnotetext{
"50:50, bergaya dengan khas diri sendiri akan membuat tingkat kepercayaan diri meningkat. Tentu saja masih mengikuti fashion terkini”

"Penting karena sebagai cerminan kalau kita up to date wawasannya".

'Penting, agar tidak tertinggal jaman'”

"Sangat penting karena kita bisa mengerti perkembangan fashion style saat ini Sangat penting karena kita bisa mengerti perkembangan fashion style saat ini"

"Relatif, jika trendnya fashion yg tertutup, sopan saya akan suka, dan mungkin akan membelinya”.

"Menumbuhkan rasa percaya diri seseorang untuk tampil berbeda"

"Sangat penting, karena dengan mengikuti fashion menjadi tampil lebih pede"
}

S1 dan S2 tidak melaporkan kasus pelecehan seksual. Dapat disimpulkan bahwa adanya alasan faktor yang mempengaruhi adalah (1) Keraguan apakah hal tersebut pelecehan atau bukan, (2) Mendapatkan saran dari orang terdekat untuk tidak melaporkan, (3) tidak menginginkan ada konflik, (4) tidak mengetahui alur melaporkan kasus, (5) tidak ingin terjadi masalah dan hambatan pada proses perkuliahan, (6) meniru perilaku orang sekitar, (7) beranggapan melaporkan kasus adala tindakan yang sia-sia. 
4. Pertanyaan keempat tentang fashion yang dikenakan merupakan manifestasi dari kepribadian individu.

Tabel 4

Fashion Merupakan Manifestasi Kepribadian Individu

\begin{tabular}{llll}
\hline No & Respon & Jumlah & Prosentase \\
\hline 1 & Tidak atau belum tentu & 30 & 10 \\
\hline 2 & Kemungkinan & 41 & 13,6 \\
\hline 3 & Iya & 200 & 66,4 \\
\hline 4 & Tidak tahu & 30 & 10 \\
\hline Jumlah total & 301 & 100 \\
\hline
\end{tabular}

Respon dari 301 responden menyatakan bahwa 66,4\% responden atau sekitar 200 responden menjawab bahwa fashion yang dikenakan oleh individu merupakan respresentasi atau cerminan dari gambaran kepribadian individu. 13,6\% atau 41 responden menjawab kemungkinan bahwa fashion yang dikenakan oleh individu merupakan respresntasi dari kepribadiannya, sedangkan sisanya 30 Responden atau $10 \%$ dari responden menjawab bahwa fashion yang dikenakan tidak ada kaitannya atau tidak tahu bahwa fashion yang digunakan seseorang berkaitan dengan kepribadian pemakainya. Berikut beberapa respon dari responden.

"menurut saya benarr. karena terlihat bagaimana selera seseorang, cara berpakaian rapih atau tidak menunjukkan kepribadiannya”

"Iya, karena ajining diri saka busana. Karena penilaian pertama seseorang dari pakaian, apa yg dia lihat, baru lisan, ajining diri saka lathi”.

"Tentu fashion yang dipakai berkaitan dengan karakter seseorang, kalau di bahasa jawa itu ajaning diri saka busana. Jadi kita dapat menilai bagaimana sifat seseorang apakah dia orang yang rapi atau tidak”

"Pakaian yg dipakai dapat mencerminkan kepribadiaan seseorang, karena dari busana tersebut memiliki makna masing masing. Contoh dari segi pemilihan warna, motif, atau model pakaian yg digunakan”.

"Tidak, karena ada sebagian org yg hanya ikut" fashion terkini padahal dalam dirinya sendiri ia tidak nyaman menggunakan apa yg ia pakai”.

"Ya, karena seseorang dapat menuangkan kepribadiannya baik sengaja ataupun tidak melalui cara berpakaiannya, hal itu dapat dilihat dari aspek warna, aliran fashion seperti boyish atau feminin, dan aspek lain dalam pemilihan mode busana yang dipilih oleh seseorang untuk di kenakannya" 
5. Pertanyaan kelima tentang dampak mengikuti fashion terkini atau trend mode.

\section{Tabel 5}

\section{Dampak Fashion Involvement}

\begin{tabular}{llll}
\hline No & Dampak dari fashion involvement & Jumlah & Prosentase \\
\hline 1 & Boros & 29 & 9,6 \\
\hline 2 & Bahan perhatian & 16 & 5,3 \\
\hline 3 & Fashionable & 30 & 10 \\
\hline 4 & Focus pada penampilan & 12 & 4 \\
\hline 5 & Percaya diri & 80 & 26,6 \\
\hline 6 & Kreativitas meningkat & 10 & 3,3 \\
\hline 7 & Tidak ketinggalan zaman & 66 & 22 \\
\hline 8 & Menambah relasi perteanan (senang, bangga) & 10 & 3,3 \\
\hline 9 & Menambah wawasan tentang fashion & 10 & 3,3 \\
\hline 10 & Memperoleh pengakuan dari orang lain & 15 & 5 \\
\hline 11 & Menjadi trendsetter & 18 & 6 \\
\hline 12 & Kepuasan Diri & 10 & 3,3 \\
\hline Jumlah total & 301 & 100 \\
\hline
\end{tabular}

Terdapat berbagai respon dampak seseorang mengikuti trendfashion terkini antara lain; menambah percaya diri, fashionable, menjadi trendsetter, merasa senang, bangga, menambah kepuasan diri, menambah kreativitas, menambah wawasan, menambah pertemanan, menjadi pusat perhatian, tidak ketinggalan zaman, impulsive buying atau boros, memperoleh pengakuan dan apresiasi dari orang lain, harga diri menjadi meningkat dan lain sebagainya. Berikut ini beberap respon responden terkait dampak mengikuti fashion terkini.

"untuk meningkatkan rasa percaya diri karena merasa tidak tertinggal dengan trend yang adaa. namun ada dampak positif dan negatif nya, karena seseorang tidak selalu cocok mengenakan busana tertentu, disesuaikan dengan bentuk tubuh dan warna kulit juga, jika terlalu memaksakan akan terlihat aneh"

“dampak positif: Seseorang dapat menjadi lebih up to date, Tidak ketinggalan jaman, Penampilan lebih fresh, Tampil percaya diri di depan umum krn fashion yg dikenakan sedang trend"

"Dapat menjadi lebih kreatif dalam berbusana yang di sesuaikan dengan keinginan dan kepribadian kita masing2 sehingga dapat lebih percaya diri dalam mengenakan busana"

"Terlihat lebih kekinian dan keren di mata orang lain, terlihat memiliki status yang lebih tinggi, terkesan sebagai fashionista” 
"Tampilan terlihat lebih fresh, kepuasan diri terpenuhi, menambah nilai diri dalam pergaulan"

"Kemungkinan besar ada yang bertujuan memang untuk menyenangkan diri sendiri, ataupun ingin terlihat menjadi seseorang yang up to date akan perkembangan zaman, serta ada ingin terlihat cantik atau tampan sesuai dengan idola mereka dsb".

\section{Pembahasan}

Fashion merupakan salah satu cara remaja mengekspresikan diri dan menemukan identitas dirinya, dengan cara mengikuti perkembangan fashion terkini para remaja merasa bahwa diri mereka mampu memperluas jangkauan persahabatan maupun pengetahuan serta mendongkrak tingkat populeritas mereka pada lingkungannya. Dengan menggunakan gaya berpakaian yang kekinian, unik, branded membuat remaja merasa mampu menemukan jati diri, persahabatan, berdamai dengan lingkungan dan perkembangan tenologi, pun sebaliknya mereka merasa kuper, kudet dan сири ketika tidak mengetahui dan menggunakan gaya berpakaian sesuai dengan trend fashion terbaru, sehingga mengakibatkan mereka dijauhi oleh teman sebayanya karena dianggap aneh (Auty dan Elliot, 1998).

Hal ini sesuai dengan hasil penelitian Chusniasari (2015) menghasilkan bahwa fenomena outfit of the day (OOTD) atau sering disebut sebagai pakaian yang akan dipakai hari ini, membuat remaja lebih senang dan percaya diri, mendapatkan apresiasi oleh orang lain atau teman sebayanya jika mereka menggunakan outfit atau fashion terbaru dan mengikuti trend fashion yang sedang hits serta up to date tentang informasi fashion dengan tujuan ingin menjadi trendsetter dikalangan teman sebayanya. Remaja berusaha mencari informasi- informasi seputar fashion melalui berbagai cara diantaranya dengan mencari informasi di kalangan komunitas fashion yang sedang diharapkan.

Busana merupakan bagian dari fashion merupakan suatu kebutuhanpenting yang harus dipenuhi dalam kehidupan individu, karena itulah busana merupakan salah satu indikator pencetus kemunculan dan berkembangnya life style atau gaya hidup, hal ini senada pendapat Featherstone (2001) mendiskripsikan bahwa fashion selalu disinonimkan dengan busana, padahal arti secara luas fashion meliputi adornment, style maupun dress. Hal ini diperkuat oleh Thio (1989) menjelaskan bahwa fashion merupakan novelty atau kebaruan, karena fashion selalu bergerak 
dan berubah sesuai dengan perkembangan zaman maka fashion sering diidentikan dengan busana.

Menurut Bernard (2006) menyatakan bahwa fashion merupakan "the language of fashion" artinya bahwa setiap produk fashion memiliki pesan makna yang ingin disampaikan oleh individu kepada orang lain. Dengan kata lain bahwa dengan fashion seseorang berusaha mengkomunikasikan hal-hal tentang dirinya kepada orang lain, karena fashion merupakan bagian dari bentuk ekspresi diri pemakaianya dengan menunjukkan nilai, status, kepribadian, identitas, perasaan dan suasana hatinya.

Fashion dalam realitas sosial memiliki beberapa nilai yang terkandung di dalamnya, dengan menggunakan fashion pemakainya berusaha untuk menyampaikan pesan secara nonverbal kepada orang lain. Menurut Barthes (1967) dalam sebuah teori semiotika menjelaskan bahwa suatu obyek tertentu mampu menjelaskan dan menyampaikan makna yang tersirat di dalamnya. Begitu halnya dengan fashion tidak hanya sebagai cover of the body tetapi memiliki makna yang tersirat secara implisit maupun eksplisit kepada orang lain.

Berbagai macam tujuan individu menggunakan fashion diantaranya adalah; 1) Ingin terlihat lebih menarik atau be attractive, 2) Membuat kesan diri pada orang lain atau impress other, 3) Menjadi symbol penerimaan oleh teman sebaya dan kelompok sosial atau be accepted by friends, peer grups or colleagues, dan 4) Sebagai bentuk penyaluran kebutuhan psikologis atau fill in emotional need (Farhad, Jasour, Shirpour dan Alizadeh, 2012).

Menurut Hossein, Afsin, dan Sayed (2014) menyatakan dalam penelitian terdapat beberapa dampak negatif fashion involvement yaitu impulse buying, meningkatnya perilaku konsumtif dan shoping lifestyle, hasil penelitian ini diperkuat oleh Pattipeilohy (2013) yang menyatakan bahwa fashion involvement berkorelasi positif dengan impulse buying, artinya semakin tinggi fashion involvement seseorang maka akan memiliki resiko impulse buying lebih besar. Farhad, Jasour, Shirpour dan Alizadeh (2012) dalam penelitiannya menghasilkan bahwa individu yang memiliki fashion involvement akan memungkinkan terlibat dalam pembelian pakaian lebih besar dibandingkan individu yang tidak memiliki fashion involvement. 
Tyaswara, Taufik, Suhadi dan Danyati (2017) dalam penelitiannya menyatakan bahwa trend fashion style dikota besar termasuk Bandung di dominasi dengan fashion hijaber, casual formal, formal, elegan dan glamour, karena menurut subyek menyatakan bahwa fashion memiliki sifat dinamis dan mengikuti perkembangan trend terkini serta berubah-ubah. Hasil penelitian ini juga di dukung oleh Mega (2017) menyatakan bahwa fashion terkini yang dijadikan kiblat remaja saat ini adalah model casual, glamor, branded karena mereka mengikuti trend para public figure serta perkembangan zaman.

\section{Kesimpulan}

Kesimpulan dalam penelitian ini adalah;

- Responden menyatakan bahwa trend model terkini adalah casual, pada masa 1990-an, fashion muslim atau menutup aurat, Korean dan western style, fashionable, branded, elegant, unik, bohemian style, rose fashion stayle dan memiliki aksen dan warna tertentu.

- Sebesar 97,7\% responden memiliki koleksi fashion terkini lebih dari satu dan sisanya menyatakan tidak memiliki.

- Terdapat 55 responden atau sebesar 18,3\% responden menjawab bahwa mengikuti fashion terkini merupakan suatu hal yang sangat penting dalam menunjang penampilan diri dan percaya dirinya serta wawasan yang dimiliki oleh individu, sebesar $29,9 \%$ responden atau sebenyak 90 responden menjawab cukup penting karena dengan menggunakan fashion terkini akan menjadi trendsetter bagi kalangan remaja lainnya, dan itu merupakan suatu kebanggaan dan hits di era sekarang ini, sebanyak 100 responden atau sebesar 33,3\% responden menyatakan mengikuti fashion terkini (fashion involvement) tidaklah terlalu penting, karena mereka menyadari bahwa daya tarik dan kesempurnaan penampilan tidak hanya terletak pada penggunaan fashion terkini atau pada penampilan fisik semata.

- Sebesar $66,4 \%$ responden atau sekitar 200 responden menjawab bahwa fashion yang dikenakan oleh individu merupakan respresentasi atau 
cerminan dari gambaran kepribadian individu. 13,6\% atau 41 responden menjawab kemungkinan bahwa fashion yang dikenakan oleh individu merupakan respresntasi dari kepribadiannya, sedangkan sisanya 30 Responden atau $10 \%$ dari responden menjawab bahwa fashion yang dikenakan tidak ada kaitannya atau tidak tahu bahwa fashion yang digunakan seseorang berkaitan dengan kepribadian pemakainya.

- Dampak seseorang mengikuti trend fashion terkini antara lain; menambah percaya diri, fashionable, menjadi trendsetter, merasa senang, bangga, menambah kepuasan diri, menambah kreativitas, menambah wawasan, menambah pertemanan, menjadi pusat perhatian, tidak ketinggalan zaman, impulsive buying atau boros, memperoleh pengakuan dan apresiasi dari orang lain, harga diri menjadi meningkat dan lain sebagainya.

\section{Saran}

Saran dalam penelitian ini adalah;

- Kepada remaja pada umumnya sebaiknya tidak menjadi korban trend mode, lebih bijak dan tidak impulsive buying dalam mengikuti fashion terkini terutama saat materi tidak mendukung.

- Gunakan fashion yang nyaman dan sesuai dengan kepribadian serta karakter diri agar tidak labil mudah terombang-ambing dalam mengikuti fashion terkini.

\section{Daftar Pustaka}

Andriyanto., Sukmana. D, Suyadi., I dan Fanani., D., (2016). Pengaruh fashion involvement dan positive emotion terhadap impulsive buying. Jurnal Administrasi Bisnis, Vol. 31.

Amiri, F., Jasour, J., Shirpour, M., \& Alizadeh, T. (2012). Evaluation of effective fashionism involvement factors effects on impulse buying of customers and condition of interrelation between these factors. Journal of Basic and Applied Scientific Research, 2(9), 9413-9419. 
Auty, S. and Elliot, R. (1998). Fashion involvement, self-monitoring and the meaning of brands. Journal of Product and Brand Management 7 (2), 109123.

Barnard, M., (2006). Fashion sebagai komunikasi: Cara mengkomunikasikan identias sosiasl, seksual, kelas dan gender. Diterjemahkan oleh: Idy Subandy Ibrahim. Yogyakarta \& Bandung: Jalansutra.

Chusniasari, (2015). Pengaruh shopping lifestyle, fashion involvement dan hedonic shopping terhadap impulse buying pelanggan. Jurnal Ilmu dan Riset Manajemen, Vol. 4.

Farhad.A., Jasour.J., Shirpour.M., and Alizadeh.T., (2012). Evaluation of effective fashionism involvement factors on impulse buying of costumers and condition of interrelation between these factor. Journal of Basic and Applied Scientific Research. 2(9), pp: 94139419.

Fairhurst, A. E., Good, L. K., \& Gentry, J. W. (1989). Fashion involvement: an instrument validation procedure. Clothing and textiles research journal, 7(3), 10-14.

Fenigstein, A., Scheier, M., and Buss A. (1975). Public and private selfconsciousness: assessment and theory. Journal of Consulting and Clinical Psychology, 43 (4), 522-527.

Featherstone, Mike. (2001). Posmodernisme dan budaya konsumen. Pustaka Pelajar.

Gutman, J. and Mills, M.K. (1982), "Fashion life style, self-concept, shopping orientation, and store patronage: an integrative analysis", Journal of Retailing, Vol. 58 No. 2, pp. 64-86.

Goldsmith, R. (2002). Some personality traits of frequent clothing buyers. Journal of Fashion Marketing and Management, 6 (3), 303-316.

Goldsmith, R., Moore, M. and Beaudoin, P. (1999). Fashion innovativeness and self-concept: A replication. Journal of Product and Brand Management, 8 (1), 7-18.

Hossein V., Afsin. R., Seyed. J.M., (2014). Evaluation of the influence of fashion involvement, personality characteritics, tendency to hedonic consumption and store environemt on fashion-oriented impulse buying. Mediterranean journal of social sciences MCSER publishing, Rome-Italy. Vol. 5 No. 16, July

(http://carapandangku.blogspot.com/2011/07/pengujianhipotesis-regresilinier.html). 
Hendariningrum, R., Susilo.E., (2008). Fashion dan gaya hidup: Identitas dan komunikasi. Jurnal Ilmu Komunikasi. Volume 6. Nomor 2. Halaman 25-33. Diambil dari: https://media.neliti.com/media/publications /103100-IDfashion-dan-gaya-hidupidentitas-dan-kom.pdf. (27 September 2017

Iravania. M.R., Ghojavanda.K., Taghipourb.F., dan Masomi.Y., (2012). “A social work study on the relationship between personality traits, prestige sensitivity, and fashion consciousness of Iranian students", Growing Science Ltd. 2(8) pp.3055-3060/2012.

Japrianto. E., dan Sugiharto.S., (2011). Pengaruh shopping lifestyle dan fashion involvement terhadap impulse buying behaviour masyarakat high income di surabaya. Jurnal Manajemen Pemasaran, Vol.6, NO. 1, April 2011:32-41.

Kim, H., (2005), Consumer profiles of apparel product involvement and values. Journal of Fashion Marketing and Management.

Levy, M and Weitz, B. A., (2009), Retailing Management, Seventh Edition, Mc Graw Hill.

Moleong, Lexy J. 2014. Metodologi Penelitian Kualitatif. Bandung: Remaja Rosda Karya.

Morissan M. dkk., (2012). Metode Penelitian Survei . Jakarta: Kencana.

Mega, A., (2017). Perkembangan Trend Fashion di Indonesia (On-Line), tersedia di https://www.kompasiana.com/annisamega/588321f3cc92731105931d89/p erkembangan-trend-fashiondi-indonesia?page=all. Oleh Anisa Mega, di akses pada tanggal 21 September 2020 pukul 17.08 WIB.)

Pattipeilohy V. R., (2013). The influence of availability of money and time, fashion involvement, hedonic consumption tendency, positife emotions toward impulse buying behaviour in Ambon City. International Journal of busins and behaviooural sciences. Vol. 3, No. 8; August 2013.

Prastia, F.E., (2015). Pengaruh shopping lifestyle, fashion involvement dan hedonic shopping value terhadap impulsive buying behavior pelanggan (Toko Elizabeth Surabaya).

Park, F. and Lennon, S. (2006) "Psychological and environmental antecedents of impulse buying tendency", Journal of Consumer Marketing, vol. 23, No. 2 pp 56-66.

Phau, I., \& Lo, C. C. (2004). Profiling fashion innovators: A study of self-concept, impulse buying and Internet purchase intent. Journal of Fashion Marketing and Management, 8(4), 399-411. 
Singarimbun, M., (1989). Metode Penelitian Survei. Jakarta: LP3ES.

Setiadi, I.M.W dan Warmika.I.G.K., (2015). Pengaruh fashion involvement terhadap impulsive buying konsumen fashion yang dimediasi positive emotion di kota denpasar. EJurnal Manajemen Unud, Vol. 04. 